\title{
1 A Long-term Analysis of the Historical Dry Boundary for the Great Plains of North \\ 2 America: Implications of Climatic Variability and Climatic Change on Temporal and \\ 3 Spatial Patterns in Soil Moisture
}

4

5 Shawn W. Salley ${ }^{1}$, , Richard O. Sleezer ${ }^{2}$, Robert M. Bergstrom ${ }^{3}$, Patrick H. Martin ${ }^{4}$, 6 Eugene F. Kelly

$81^{1 *}$ shsalley@nmsu.edu, Research Soil Geographer, USDA-Agricultural Research Service, Jornada

9 Experimental Range, MSC 3JER, NMSU, Box 30003,Las Cruces, NM 88003-8003, USA

10

${ }^{2}$ rsleezer@emporia.edu, Associate Dean, Liberal Arts \& Sciences, Roosevelt Hall, 1 Kellogg Circle, Emporia State University, Emporia, Kansas 66801, USA

${ }^{3}$ rbergstr@westga.edu, Faculty, University of West Georgia, Geosciences Department, Callaway Building, 1601 Maple Street, Carrollton, GA 30118, USA

${ }^{4}$ patrick.martin@colostate.edu, Associate Professor, Department of Horticulture \& Landscape Architecture, Colorado State University, 1173 Campus Delivery, Fort Collins, CO 80523-1173, USA

5 eugene.kelly@colostate.edu, Professor, Department of Soil \& Crop Sciences, Colorado State University, 1170 Campus Delivery, Fort Collins, CO 80523-1173, USA

$23 *$ Corresponding author 
The boundary between the humid eastern and the arid western regions of the Great Plains of

3 North America is of great economic interest and historic intrigue, yet its location is controversial.

4 Areas to the east of this boundary have historically enjoyed the benefits of fertile soil coupled

5 with more favorable rainfall and reliable surface water, permitting conventional agriculture to

6 flourish over a remarkably large percentage of the eastern Great Plains. The expansion of

7 population and agriculture during the nineteenth century across the western Great Plains tested

8 the extent that non-irrigated, row crop agriculture could be successful in areas where year-to-year

9 rainfall was unreliable. In this paper, we quantify the historic annual variability of soil moisture

10 and hydrologic conditioning in the Great Plains resulting from climatic variability, show the

11 regions that historically demonstrate unreliable precipitation, and identify the extent of arid

12 regions of the central United States based on modeled annual soil moisture variability. We asked

13 how arid climates have influenced soil formation patterns at small cartographic scales, and how

14 soil properties buffer or enhance soil moisture regimes (at the udic-ustic boundary) to climate

15 variability at larger cartographic scales. At small cartographic scales, a climate-only model

16 worked nearly as well as a climate-and-soils model in mapping the region's soil moisture

17 boundary; however, a climate-only model missed important local soil influences. Finally, we

18 demonstrate that long-term climate and climate variability are reflected in the depth and

19 concentration of the calcic soil properties. From a practical standpoint, our work highlights that

20 soils with higher water holding capacity dampen periodic short-term rainfall deficits, while soils

21 with lower water holding capacity can exhibit edaphic drought during otherwise normal climate

22 years. 


\section{1. Introduction}

2 In John Wesley Powell's landmark 1878 report on the arid lands of the Western United

3 States, he wrote that when moving across the Great Plains from east to west at approximately the

4 midway point of the United States there begins a region "so arid that agriculture is not successful

5 without irrigation" (Powell et al., 1879). Powell deemed this boundary between the humid region

6 and the arid regions corresponded with the 20 -inch $(50.8 \mathrm{~cm})$ isohyet of annual precipitation,

7 assuming that precipitation was evenly distributed throughout the year. Today, the 20 inch

8 isohyetal boundary would be considered arbitrary because it does not consider differences in

9 evapotranspiration associated with temperature gradients from south to north or the seasonal

10 distribution of precipitation in the Great Plains where more precipitation falls during spring and

11 summer months of the year (Hoerling et al., 2014). The 20 inch isohyetal boundary, falling

12 approximately along the 100th Meridian, does however, approximate the normal westward reach

13 of moist air from the Gulf of Mexico due to the interaction of upper level air masses from the

14 Pacific Ocean and surface outflow from the Gulf of Mexico (Forman et al., 2001).

15 Settlement of the North American Great Plains began at the end of the American Civil War

16 with agricultural lands encroaching on the 100th Meridian by the 1870s (Lewis, 1966). Since

17 Powell's report on the western lands, agroecosystems have expanded westward well beyond the

18 20-inch isohyetal line of annual precipitation, resulting in drastic impacts on the historic native

19 landscape (Libecap and Hansen, 2002). Increased exploitation of the pedosphere by human

20 activity marks a turning point in our history where agriculture has grown to become the primary

21 impact on Great Plains ecosystems. As soil properties are the key integrator of long-term climate

22 for agroecosystems (Parton et al., 1987), it is important to recognize changes in soil climate

23 zones during this period. 
The dramatic expansion of agricultural activities in the $20^{\text {th }}$ Century across the Great Plains

2 has made the potential response of soil moisture to climate change of interest to land managers

3 and policy makers. In particular, the frequency, duration, and depth of droughts are of interest,

4 given the history of severe drought in the region during the 1930s, 1950s, 1980s, and most

5 recently in 2012-2013. Extreme drought conditions occurring in many portions of the Great

6 Plains in the past decade have stimulated research on the ecosystem consequences of more

7 frequent summer droughts and increases in temperature within this region resulting from broader

8 global increases in temperature. This work has shown that the Great Plains are becoming

9 increasingly vulnerable to drought due to an increase in the cultivation of marginal lands and the

10 depletion of groundwater from the Ogallala Aquifer (Little, 2009; Steward et al., 2013). Climate

11 models vary regarding projections of annual precipitation trends in the region (IPCC, 2014;

12 Zobeck and Daugherty, 1982), but there is a general consensus that variability in the

13 hydrological cycle is intensifying - with the most likely future climatic scenario predicting an

14 increase in the frequency of extreme precipitation events and greater inter-annual variation in

15 precipitation (IPCC, 2014).

16 One of the early attempts to classify soils in the United State divided them at the highest

17 level into pedocals and pedalfers (Marbut, 1935). The Pedocal-Pedalfer soil boundary was

18 defined as a zero line where mean annual precipitation and evapotranspiration were equal (Jenny,

19 1994). Pedocal soils were distinguished by the assumption of an accumulation of calcium and

20 magnesium in the form of pedogenic carbonates in arid or semi-arid regions, while pedalfer soils

21 were identified by the absence of carbonates and were enriched in aluminum and iron

22 sesquioxides in humid regions. The now generally antiquated terms of pedocal and pedalfer are

23 still used in quaternary geology and soil geomorphology to distinguish arid and humid soil 
1 climatic zones (Monger and Martinez-Rios, 2000). The boundary between the semi-arid and

2 humid climate regimes also still exists in U.S. Soil Taxonomy at the suborder level, and a basic

3 wet-dry categorization has evolved into the modern soil moisture regime's conceptual

4 framework (e.g., udic, ustic, and aridic). However, soil moisture classes were originally based on

5 their agricultural usage (Forbes, 1986). For example, aridic soils are defined as typically too dry

6 to support crops without irrigation, ustic soils support crops that are drought tolerant, and udic

7 soils do not require irrigation to successfully grow crops.

8 The udic-ustic soil moisture boundary is of interest to biogeographers as it approximates the

9 boundary between the Bluestem Prairie and the Mixed Prairie (Küchler, 1964). Biogeographers

10 in general have long sought the identification of boundaries between ecosystems using

11 vegetation zones or indicator species to approximate ecosystem boundaries (Küchler, 1970);

12 however, soil geographers cannot rely only on the vegetation to define ecological regions due to

13 compensation factors in the soil that override the climatic effect on vegetation (Bailey, 2004). It

14 is also likely that there is a lag time between vegetative response to climate and climate's

15 manifestation in pedogenic features. These ecotonal transition zones are also of interest for other

16 reasons. Within these transitional climatic zones soils with lower water holding capacity are

17 subject to edaphic (soil-related) droughts during normal years (Herrick et al., 2013), just as soils

18 with higher water holding capacity (as well as an increased organic matter and improved soil

19 structure) have the potential to buffer the effects of droughts on soil moisture (Lal, 2015;

20 Strickland et al., 2015).

21 The goals of this study are to (1) quantify regional inter-annual variability in the position of

22 the calcareous and noncalcareous (pedocal-pedalfer) boundary on the Great Plains based on

23 historical climatic data and soil moisture, (2) consider if soil landscapes with low water holding 
1 capacities are more sensitive to changing climate drivers, and (3) model the depth and

2 concentration of calcic soil horizons as they relate to variability in the annual water balance.

3 With these data, we can identify a generalized western limit in North America beyond which

4 agroecosystems either have to be drought tolerant or irrigated to reliably and economically grow

5 crops. In addition, we investigated the possibility that long-term climate patterns are reflected in

6 edaphic properties, and that soils with higher water holding capacity can dampen inter-annual

7 water deficits. We calculated annual continental scale soil water balance across the Great Plains

8 using soil moisture models based on monthly precipitation and temperature data from 1895 to

9 2014. With the national Soil Survey Geographic (SSURGO) database (Soil Survey Staff, 2015)

10 we then looked at the relationship between annual water balance, water holding capacity, and

11 calcic soil properties. We hypothesized that (1) soils with lower water holding capacity (e.g.,

12 coarse textured soils with low organic matter) are more susceptible to changing climate drivers

13 and short duration drought events, and (2) the increasing depth and concentration of calcic

14 horizons is positively coupled with negative long term climatic soil water balances.

\section{2. Materials and Methods}

\section{$16 \quad 2.1$ Geographic Setting}

17 Soil scientists have long recognized that the Great Plains Region of North America $\left(30^{\circ}-\right.$

$1850^{\circ} \mathrm{N}, 105-95^{\circ} \mathrm{W}$ ) is an exceptional natural experiment in the role of climate as a soil-forming

19 factor (Arkley, 1963; Jenny, 1994; Retallack, 2005; Ruhe, 1984) with east-to-west precipitation

20 gradients and north-to-south temperature gradients driving soil formation processes. While

21 climate varies markedly across the region, the variations of other soil formation factors are

22 relatively modest (Retallack, 2005), due to the soil's age (consistently younger than 14ka),

23 uniform surficial loess parent material, rolling-to-flat topography, and historically ubiquitous 
1 grassy plant communities. With this natural arrangement, the role of climate in the soil formation

2 of the Great Plains can generally be interpreted along climatic gradients, displaying increasing

3 temperatures from north-to-south and increasing moisture from west-to-east, allowing a coupled

4 hydrologic and climatic model to reliably characterize soil moisture regimes from the climate

5 record. Long-term (millennial scale) climate patterns imprint pedogenic properties on the soil

6 (Monger and Rachal, 2013), allowing scientists to recognize long-term soil moisture regimes

7 through an evaluation of the soil pedon, or more broadly, to derive soil moisture classes (for

8 taxonomic classification purposes) from climatic data using deterministic soil moisture models

9 as currently practiced in the United States (Newhall and Berdanier, 1996; Van Wambeke et al., 10 1986).

\section{$11 \quad 2.2$ Newhall Simulation Model}

12 The Newhall Simulation Model (NSM) was used to compute soil moisture regimes according

13 to methodology used in USDA Soil Taxonomy (Newhall and Berdanier, 1996; Soil Survey Staff,

14 2014). The NSM simulates monthly water balance patterns of soil moisture in relation to the soil

15 moisture control section (MCS) as a means to define the taxonomic class of soil climate. The

16 MCS of the soil is defined by an upper boundary to which a dry soil (>1500 kPa tension, but not

17 air-dry) will be "moistened" by $2.5 \mathrm{~cm}$ of water within 24 hours and a lower boundary where the

18 depth to which a dry soil will be moistened by $7.5 \mathrm{~cm}$ of water within 48 hours (Soil Survey

19 Staff, 2014; Zobeck and Daugherty, 1982). The stepwise NSM simulates downward movement

20 of moisture into the soil profile based on the amount of water needed to bring all the soil above

21 field capacity. Rate of soil water depletion depends on energy available for moisture extraction

22 through calculated potential evapotranspiration. Soil water gains and losses are limited to the 
1 soil's water holding capacity, expressed as the difference between field capacity and permanent

2 wilting point.

\section{$3 \quad 2.3$ Great Plains Simulations}

$4 \quad$ We used an updated Newhall model, java version 1.6.0 (Soil Survey Staff, 2012), to simulate

5 taxonomic soil moisture regime, soil temperature regimes, annual water balances, and summer

6 water balances for individual years. Spatially explicit soil mapping was created using the grid

7 element Newhall simulation model methodology (Winzeler et al., 2013) by running raster cells

8 in annual mode and then merging batched model runs back into an annual geographic

9 representation. Year by year analysis was favored due to model limitations and to support our

10 research goal of quantifying inter-annual variability in the spatial prediction of calcareous and

11 noncalcareous soils.

12 Simulations of soil hydrologic properties were parameterized with average monthly data

13 from 1895 to 2014 using the precipitation and temperature 4-km PRISM data (PRISM Climate

14 Group, 2015). We used a default of $2.5^{\circ} \mathrm{C}$ mean annual soil-to-air offset. Root-zone available

15 water capacity was derived from the continuous United States (CONUS) USDA-NRCS digital

16 general soil map (Miller and White, 1998; Soil Survey Staff, 2006). Ground water conditions

17 were not considered at our scale of analysis ( 800 meter resolution) as the effects of ground water

18 were deemed insignificant along the annual pedocal-pedalfer boundary. This particular analysis

19 only considered broad regional scale patterns of the udic-ustic boundary location and not the

20 specific finer-scale intergrade patterns of soil moisture regimes.

21 Interannual maps were derived using annual soil water balance and soil moisture regime

22 outputs of the NSM. For annual soil water balance, where net water balance was equal to zero

23 (PPT=PET), we digitized an isohyetal line from north to south across the Great Plains. Similarly, 
1 where the NSM predicted the border between udic and ustic moisture regimes, we created

2 binomial raster grids $(1,0)$ where aridic and ustic regimes had a value of one and udic and

3 perudic regimes had a value of zero. By summarizing raster grids, a spatial distribution of soil

4 moisture conditions was established, creating the basis for our analysis of the temporal scale of

5 what amounts to the soil pedocal/ pedalfer line as it fluctuated from 1895 to 2014 .

6 Mapping tasks were performed using ArcGIS 10 software (ESRI, 2014). Grid-point

7 population models were performed in geographic coordinate system-WGS72 datum and all area

8 estimates were made using Albers equal area projection (NAD83, USA Contiguous Albers Equal

9 Area Conic). Higher resolution raster and vector data were resampled and rasterized to a

10 common target of 2.5 arc minutes of a geographic degree, or approximately a $4 \mathrm{~km}$ pixel

11 resolution. Relationships between variables (climatic, physiographic, and edaphic) and the

12 latitudinal geographic discrepancy of the pedocal-pedalfer and the PPT=PET isohyet (where

13 precipitation equals evapotranspiration) were tested using regression analysis. Statistical analyses

14 were computed using the open-source statistical analysis package PAST v3.08 (Hammer et al.,

15 2001).

\section{$16 \quad 2.4$ Calcic Soils}

17 Calcic horizon depth and concentration data were queried via soil taxonomic classification

18 and dominant condition from the National Soil Information System (NASIS) database using soil

19 data access and joined to the USDA NRCS's gridded Soil Survey Geographic Database

20 gSSURGO GIS data layer for analyses (Soil Survey Staff, 2014). To mimic climo-sequence

21 functions (Jenny, 1994), calcic horizon data were constrained to include only soils that would

22 represent long-term soil development without significant erosion or deposition (such as

23 geomorphic interference). The focus was on soils formed with gently sloping or low topographic 
1 relief, soils showing sufficient pedogenic development, soils with similar biological history, soils

2 with similar parent material (e.g., loess), and soils in the geographic region of the southern Great

3 Plains. The methodology was designed to resemble an approach described by Retallack

4 (Retallack, 2005), but with soil component level data.

5 To satisfy the requirement of similar age soils, we included soil with well-developed argillic

6 horizon and excluded Entisols and Inceptisols. Alfisols were excluded to focus on soils assumed

7 to have formed under a grassland biomes. Alfisols in the southern Great Plains typically

8 represent either eroded phases of Mollisols (removal of the mollic epipedon) or lowland savanna

9 associated soils. To satisfy similar parent material conditions, we excluded soils with vertic

10 properties and/or shallow lithic contacts while also limiting analyses to soils with similar textures

11 as measured by particle sizes in the gSSURGO database. We defined the Southern Great Plains

12 as areas defined by NRCS Major Land Resource Areas 72, 73, 77A, 77E, and 77D (USDA-

13 NRCS, 2006).

14 Soil $\mathrm{CaCO}_{3}$ was reported from NASIS as weight percentage (i.e., > 2-mm size fraction) and

15 to which we used the representative component values. A subset of the queried horizon data was

16 selected for statistical analyses. This subset was also tested for spatial autocorrelation using

17 Global Morran's-I, a statistical method to detect if pattern clusters are random and decrease the

18 chance of type 1 error. A standard least squares regression was performed between the subset of

19 calcic soils data and the long-term average (1895-2014) of annual water balance output from the

20 NSM. This analysis was completed at a larger cartographic scale than the soil moisture regime

21 simulation modeling.

22 3. Results 
We first present results of long-term soil moisture simulations and annual water balance in

2 the Great Plains. These findings were expanded by our results of variability of soil climate

3 conditions for the entire record, the differences between the first half and second half of the

4 record, average conditions during droughts of the 1930s and 1950s, and the soil moisture regimes

5 during the most arid years on record. We then focused on relationships between climatic,

6 physiographic, and edaphic properties and the latitudinal geographic discrepancy of the pedocal-

7 pedalfer and the PPT=PET isohyet. Finally, we present results of the calcic soil properties as

8 they relate to the long-term water balance trend.

\section{$9 \quad$ 3.1 Pedocal-Pedalfer Dynamics}

10 The long-term eastern soil moisture boundary of the "arid west" closely mimics the isohyet

11 where precipitation equals potential evapotranspiration (Fig. 1). A fundamental result is how

12 minor the general east-to-west trend was in the boundary moving from south to north, despite

13 large differences in temperature along this latitudinal gradient. The largest discrepancy between

14 these boundaries occurred in northern Nebraska and central Texas where the climate-and-soils

15 boundary occurred east of the climate only boundary. The eastward shift in Texas corresponds

16 with higher annual water balance seen in the interior coastal plain and Buckland Prairie, while

17 the eastward shift in Nebraska coincides with higher elevation, lower available water capacity,

18 and higher annual water balance (Fig. 3). The soil moisture boundary occurred slightly westward

19 in areas with higher root-zone available water capacities (Fig. 3), such as in western Kansas's

20 deep loamy soils and in North Dakota drift prairie. Generally, the long-term average of the

21 annual pedocal-pedalfer soil isohyet (blue line, Fig. 1) falls in line with the traditional view of

22 climate and soil moisture patterns in the Western Great Plains as espoused by Powell. 
To quantify the variability of soil climate (the spatial extents of udic and ustic moisture

2 classes), we grouped results into: the driest extent (maximum drought), driest decile (driest

$310 \%$ ), driest quartile (dry 25\%), wettest quartile (wet 25\%), wettest decile (wettest 10\%), and

4 wettest extent (maximum wet) for the study area (Fig.s $2 \mathrm{a}$ and $2 \mathrm{~b}$ ). The maximum extent of dry

5 soil climate (green line, Fig. 2a) extends well into Minnesota, Iowa, Missouri, and even Illinois,

6 as that extent corresponds to expanded ustic conditions simulated during the droughts of 1934

7 and 1936. Our results show that the maximum wet extent (red line, Fig. 2a) simulated udic soil

8 moisture conditions extending to the Pecos River in New Mexico and Davis Mountains of west

$9 \quad$ Texas and corresponds with record rainfall during 1941.

10 Overall, the first half of the record (1895-1954) was found to be slightly drier than the

11 second half (1955-2014), with the greatest departures from the long-term average conditions

12 occurring in Oklahoma and especially Texas; however, the boundaries in the two periods were

13 very similar in Kansas and northwards (Fig. 2c). These records closely mimic the long-term

14 average spatial pattern of regional climate within the Great Plains.

15 Spatial patterns of soil moisture during the two most significant droughts for the Great Plains

16 (1931-1939 and 1952-1956; Fig. 2d) mimic the driest quartile (blue line, Fig. 2a). We detected a

17 pattern in North Dakota (Fig. 2d) where our model simulated higher soil moisture contents

18 during the drought of 1952-1956 than compared with the 1931-1939 drought. Another notable

19 difference between the spatial patterns of these two droughts occurred in the central portion of

20 the Great Plains where the 1950s drought extended farther east than the more famous drought of

21 the 1930s in Kansas and Oklahoma. We further quantified the wettest and driest years based on

22 the total area of aridic, ustic, and udic soil moisture regimes (Table 1). Of particular interest is

23 the spatial distribution of aridic and ustic classes for the three most extreme dry years (Fig. 4). 
1 During these year, typic-aridic moisture classes (MCS moist for less than 45 days) extended into

2 Wyoming and Nebraska and extreme-aridic moisture classes (MCS dry for whole year) were

3 appreciable in eastern Colorado, western Kansas, the Oklahoma panhandle, and New Mexico.

$4 \quad 3.2$ Boundary Relationships

5 Results of regression of the climatic, physiographic, and edaphic properties and the east-west

6 differences of the pedocal-pedalfer and the PPT=PET isohyet are presented in table 2. A

7 significant positive relationship was found with change in precipitation $(r=0.842)$, temperature

$8(\mathrm{r}=-0.444)$, potential evapotranspiration $(\mathrm{r}=0.581)$, annual water balance $(\mathrm{r}=0.713)$, and

9 summer water balance $(\mathrm{r}=0.510)$. While a significant negative relationship was found with total

10 plant available water capacity $(r=-0.623)$ and change in elevation $(r=-0.888)$. By plotting these

11 variables by latitude (Fig. 3), the wide disagreement between the two boundaries in Nebraska is

12 explained by higher annual water balance, lower plant available water capacity, and higher

13 elevations, while areas with discrepancies in Texas were explained by higher annual water

14 balances alone.

\section{$15 \quad 3.3$ Calcic Soils}

16 The distribution of calcic soil horizons in the study area were primarily located east of the

17 Marbut line (Fig. 5). Calcic soils located in North Dakota, South Dakota and Minnesota are

18 mostly Calciaquolls and Calcic Hapludolls, with Calciustolls and Calciustepts making up most of

19 the other northern calcic soils. South of the $40^{\text {th }}$ parallel (the northern boundary of Kansas),

20 calcic soils make up a larger portion of landscape and are a mix of soils that are predominantly

21 Mollisols, Inceptisols, and Aridisols containing calcic soil horizons. A statistically significant

22 relationship was found between both the depth and concentration of $\mathrm{CaCO}_{3}$ in a soil with the

23 long-term annual water balance (in $\mathrm{mm}$ ) in the Southern Great Plains (Fig. 6). The concentration 
1 of $\mathrm{CaCO}_{3}$ showed a negative relationship ("slope $=-0.097$ "; $\mathrm{r}^{2}=0.342$ ), while the depth to the top

2 ("slope $=0.127 " ; r^{2}=0.101$ ) and to the bottom of calcic horizon ("slope $=0.208$ "; $\mathrm{r}^{2}=0.095$ ) both

3 reported low coefficient of determination. A poor coefficient was also found between the

4 thickness of calcic horizon and annual water balance ("slope $=-0.087$ "; $r^{2}=0.049$ ).

\section{4. Discussion}

6 The goals of this study were to (1) quantify inter-annual variability of the position of the

7 pedocal-pedalfer boundary on the Great Plains based on historical climatic data and modeled soil

8 moisture, (2) consider if soil landscapes with low water holding capacities are more sensitive to

9 changing climate drivers, and (3) model the depth and concentration of calcic soil horizons as

10 they relate to variability in the annual water balance. Due to pronounced climatic variability and

11 lack of definitive climatic, physiographic, and biogeographic characteristics of the Great Plains

12 there have been many interpretations of Great Plains geography, with interpretations increasingly

13 including culturally based criteria (Rossum and Lavin, 2000), as well as other delineations being

14 qualitative in nature (McMahon et al., 2001). Long-term soil moisture balance offers a novel,

15 rule-based criteria for defining ecoregions. Furthermore, since the timing and extent of water

16 balance fluxes governs the trajectory and degree of soil evolution (Chadwick and Chorover,

17 2001), modeling the pedoclimate offers a fundamental approach to regional landscape

18 classification.

\section{4.1 Great Plains Climate Geography}

20 Comparing our boundary of the Arid West with those of Powell and Marbut, southwestern

21 areas of the study area were demonstrated as more arid than shown by Powell and Marbut's

22 borders. Both the current National Soil Survey's (Soil Survey Quality Assurance Staff, 1994)

23 and Marbut's (Marbut, 1935) border are defined by soil properties and not climatic data. The 
1 discrepancy between our boundaries from older ones is explained by negative summer water

2 balances associated with higher evapotranspiration and lower summer precipitation in the

3 southwestern portions of the study area. A similar discrepancy occurs near the Canadian border

4 where our model shows wetter conditions further to the west than indicated by the Powell and

5 Marbut borders. In this region, lower temperatures from cold winters and short summers produce

6 a positive water balance - higher than expected by precipitation alone - due to lower annual

7 evapotranspiration values found further south.

8 Annual soil moisture patterns on the Great Plains were found to be extremely variable both

9 spatially and temporally. Spatial patterns of soil moisture in the Great Plains were influenced by

10 principles of continentality, a climatic control resulting from the influence of large land masses

11 and the remoteness of the land area from the direct climatic impact of oceans (Gimeno et al.,

12 2010). We also found that resiliency to drought was influenced by the soil's edaphic properties

13 that influence the soils capacity to store moisture. Of course, recognizing that soil moisture is

14 depleted when evapotranspiration is greater than precipitation isn't a novel observation;

15 however, our spatial representation of this phenomenon shows that there is significant variation

16 in drought sensitivity independent of climate on the Great Plains, with some landscapes more

17 and less vulnerable to drought than others. Such landscape-scale resiliency is conditional to

18 typical climatic conditions; conversely, when deep drought occurs in multiple consecutive years,

19 such as in the mid-1930s, early 1950s, and early 2010s, soil moisture storage is depleted in even

20 typically resilient areas (Fig. 2).

21 We recognized that the extreme temporal and spatial climatic variability of the Great Plains

22 restricts a precise delineation of where the arid west "begins." Our analysis could lead to

23 multiple geographic boundaries such as (1) the average boundary in figure 1 (blue line) for all 
1 the annual 1895-2014, (2) the more recent average boundary from 1955-2014 (blue line, Fig.

2 2c), or (3) even possibly a wide gradient range (Fig. 2b), or (4) even possibly the more arid dry

3 quartile (blue line, Fig. 2b). Using the arid quartile interpretation would be plausible as this

4 closely follows the 1990s NRCS Ustic-Udic boundary (blue line, Fig. 5).

$5 \quad 4.2$ Water holding capacity and edaphic droughts

6 Comparing average isoedaphic boundaries from the first half of the record (1895-1954) to

7 the second half (1955-2014) we have noted that regions of Oklahoma and Texas were actually

8 "wetter" in the second period of the record as the boundary for leaching occurs further west—as

9 much as $300 \mathrm{~km}$ west along the 32 parallel north. We believe part of this pattern is due to the

10 lower root-zone water holding capacities of these regions allowing larger apparent shifts in the

11 boundary than in regions where the soils have higher water holding capacities. Consequently

12 such a shift was not observed in western Kansas - a region of Pleistocene and Holocene loess

13 with higher root-zone water holding capacities (Ruhe, 1984). As such we have identified that

14 lower root-zone available water capacities display greater sensitivity to climate variability. In

15 general, the broader climatic drivers producing wetter conditions in the southern portion of our

16 study area for the latter half (1955-2014) are more complex, including the interaction of

17 atmospheric and oceanic currents (Forman et al., 2001). In particular, the change to warmer sea

18 temperatures in the Gulf of Mexico could have produced the incidence of higher precipitation in

19 the southeast portion of our study area (Biasutti et al., 2012).

20 Pedo-hydrologic properties of soils that limit root-zone water capacity include sandy

21 textures, shallow depth to bedrock, and the presence of a root restrictive layer (e.g., petrocalic

22 horizons). As mentioned, soils with lower root-zone available water capacities tend to be more

23 sensitive to shifts in climate. Understanding key aspects of soil development in low water 
1 holding capacity landscapes will help soil scientists understand the pedosphere's potential

2 response to climate change. We also recognize that tilled soils from agroecosystems are

3 generally expected to have decreased water holding capacity due to reduced soil organic matter

4 content, disrupted soil structure, increasing evaporative demand, and an altered spatial

5 distribution of surface water after precipitation (Seybold et al., 1999). As improved estimates of

6 past annual climates within the contemporary record become available, land use should be

7 integrated within this model framework.

\section{$8 \quad 4.3$ Cold-Xeric Soil Moisture Regimes}

9 Newhall simulations identified xeric soil moisture regimes with varying frequency in the

10 northern portion of the study area where pedologists would have typically classified these zones

11 as ustic (Soil Survey Quality Assurance Staff, 1994). Typical xeric moisture regimes are

12 characterized by wet winters with soil moisture surpluses and dry summers with large moisture

13 deficits (Soil Survey Staff, 2014). The Newhall model predicted xeric class conditions in the

14 Northern Great Plains in multiple years as a product of cold winters producing large winter soil

15 moisture surpluses and subsequently large summer deficits when temperatures and

16 evapotranspiration increased. Winzeler and others acknowledged these areas could be classified

17 as xeric (Winzeler et al., 2013); however, these "cold-xeric" soil profiles might behave

18 differently than xeric moisture regimes of warmer Mediterranean climates and different

19 biologically than the ustic soils of the western Great Plains - specifically regarding the timing of

20 deep percolation of soil water in relation to the seasonal variations in evapotranspiration. These

21 results contrast with previous studies that have shown Newhall to overestimate the ustic class in

22 xeric soils in Italy (Costantini et al., 2002), although those soils were at lower latitudes $\left(37^{\circ} \mathrm{N}\right.$ -

$\left.2346^{\circ} \mathrm{N}\right)$ than xeric soils moisture classes identified in our study area $\left(46^{\circ} \mathrm{N}-49^{\circ} \mathrm{N}\right)$. 


\section{$1 \quad 4.4$ Calcic Soils and Annual Water Balance}

2 Relationships between arid climates and soils with calcic characteristics have been well

3 documented (Dregne, 1976; Retallack, 2005), as have the relationship between calcic soil

4 horizon development and soil age (Gile et al., 1966; Machette, 1985). These assumptions of the

5 impact of climate and soil age were recognized using soil climo-sequences and soil chrono-

6 sequences (Jenny, 1994). Soil properties for our climo-sequence were selected to reduce

7 variation in topography, parent material, soil age, and vegetation to highlight the role of climate

8 in soil development across the Great Plains. While our results showed the hypothesized

9 correlation between calcic characteristics, such as the development of Bk-horizons and long-term

10 annual water balance, our regression models showed weak relationships and poor goodness of

11 fit. This observation suggests variation in the development of calcic horizon properties may not

12 be readily explained by annual water balance alone.

13 Although we have tried to implement stringent criteria to limit effects of competing factors in

14 soil formation in our climo-sequence (Jenny, 1994), this result demonstrates the continued

15 limitation of the National Soil Information Systems database for analyzing pedogenic

16 phenomenon related to calcic soils (Retallack, 2000; Retallack, 2005). Failure of our climate-

17 sequence designed to confirm established edaphic-climatic relationships, suggests that

18 component level information from this resource database may not be directly substitutable for

19 depicting a well-organized soil climo-function. Regardless, the overriding effects of climate on

20 soil landscapes (Chadwick and Chorover, 2001; Perdrial et al., 2015) should be better reflected

21 in our national soil resource databases.

\section{4. Conclusions}


In conclusion, we have defined and quantified the generalized western extent in the United

2 States in which agroecosytems would have to be either drought tolerant or irrigated to grow

3 successfully and predictably. Further research is needed to understand if these soils are trending

4 along a new climate driven soil forming vector, and more importantly the implication for the

5 management of agricultural systems given the magnitude of expected climate change. Our

6 research has implications for landscape classifications such as the Land Resource Hierarchy and

7 Major Land Resource Areas on which federal conservation programs and practices are based

8 (Salley et al., 2016). The work presented here also suggests that the extreme inter-annual

9 variability of climate on the western portions of the North America Great Plains limits reliable

10 forecasting of soil moisture, as soil moisture response in the region is exceptionally dependent on

11 the intensity and timing of precipitation. Informed management decisions regarding climate

12 change adaptation and mitigation for western lands requires a clear understanding of soil-

13 hydrologic functions of landscapes, in large part because soil hydrologic regime reveals an

14 ecosystem's inherent vulnerability to global climate change.

16 Acknowledgments: Authors thank two anonymous reviewers for their useful suggestions which 17 greatly improved the manuscript. Financial support of this research was given by the Shortgrass

18 Steppe - Long Term Ecological Research site (SGS-LTER) funded by the National Science

19 Foundation (NSF DEB 0823405 and NSF DEB 0217631). Thanks to Paul R. Finnell for help

20 with Soil Data Access query. 
1 Table 1. Summary of simulated annual soil moisture regime extremes ("driest" and "wettest" 11 years)

2 for the study area (appx. 300 million ha). The geographic extent of soil moisture regimes for 1934, 1956,

3 and 2012 are shown in Fig. 3.

4

\begin{tabular}{cccccccccccc}
\hline Soil Moisture & \multicolumn{10}{c}{ Most Arid Years (\% Study Area) } \\
\cline { 2 - 11 } Class & 1910 & 1933 & 1934 & 1936 & 1939 & 1952 & 1953 & 1954 & 1956 & 1963 & 2012 \\
\hline Aridic & 55.1 & 44.8 & 52.5 & 50.0 & 48.1 & 46.8 & 44.9 & 46.6 & 51.0 & 45.7 & 53.9 \\
Ustic & 10.8 & 9.5 & 10.0 & 5.6 & 13.6 & 16.4 & 12.4 & 7.5 & 7.0 & 10.4 & 7.8 \\
Udic & 34.1 & 45.6 & 37.4 & 44.3 & 38.3 & 36.7 & 42.7 & 45.8 & 42.0 & 43.9 & 38.3 \\
& \multicolumn{8}{c}{ Least Arid Years (\%Study Area) } \\
\cline { 2 - 11 } & 1906 & 1915 & 1919 & 1923 & 1941 & 1942 & 1985 & 1986 & 1993 & 1997 & 2004 \\
Aridic & 18.0 & 14.3 & 18.3 & 11.2 & 5.1 & 17.0 & 19.9 & 14.6 & 17.9 & 17.8 & 18.0 \\
Ustic & 5.2 & 5.2 & 5.1 & 4.6 & 2.6 & 6.5 & 4.0 & 3.0 & 4.3 & 4.8 & 2.2 \\
Udic & 76.8 & 80.4 & 76.7 & 84.2 & 92.2 & 76.5 & 76.1 & 82.4 & 77.8 & 77.5 & 79.8 \\
\hline
\end{tabular}

Table 2. Results of regression analysis between the east-west shift of the pedocal-pedalfer boundary and the PPT=PET isohyet (precipitation equals potential evapotranspiration) and climatic, edaphic,

9 physiographic properties (seen in Fig. 3).

10

\begin{tabular}{lrcrrr}
\hline \hline \multicolumn{1}{c}{ Variable } & \multicolumn{1}{c}{ Slope } & Error & Intercept & \multicolumn{1}{c}{ Error } & \multicolumn{1}{c}{$\mathrm{R}^{*}$} \\
\hline Precipitation & -0.670 & 0.070 & 3.784 & 5.030 & -0.842 \\
Temperature & -0.003 & 0.001 & -0.088 & 0.079 & -0.444 \\
Potential ET & -0.268 & 0.061 & -2.789 & 4.397 & -0.581 \\
Annual WB & -0.402 & 0.064 & 6.561 & 4.630 & -0.713 \\
Summer WB & -10.899 & 2.986 & 309.020 & 215.570 & -0.510 \\
Soil-AWC & 0.299 & 0.061 & 143.630 & 4.398 & 0.623 \\
Elevation & 1.685 & 0.142 & 4.066 & 10.240 & 0.888 \\
\hline
\end{tabular}

13 Notes: Precipitation $(\mathrm{cm})$ and Temperature $\left({ }^{\circ} \mathrm{C}\right)$ are current average annual 14 climate (PRISM Climate Group 2015, 1981-2010); Annual WB (mm), average

15 annual water balance (total precipitation minus potential evapotranspiration) for

16 all year runs (1895-2014); Summer WB (mm), average summer water balance

17 (July to Aug) for all runs (1895-2014); Potential ET, average potential

18 evapotranspiration (Thornthwaite, 1948) for all years (1895-2014); Soil AWC,

19 plant available water capacity; Elevation (m), difference between elevation of

20 pedocal-pedalfer and isohyet boundaries;

$21 *$ All regression significant $(\alpha=0.01)$. 
Fig. 1: Soil climatic boundaries of the Great Plains of North America. Green and black lines are the Powell line (1878) and the Marbut Line (1935), respectively for how they defined the boundary between the humid east and the arid west. The red line is the long-term average climatic-only boundary from the historic record (1895-2014) where precipitation equals evapotranspiration and the blue line is the longterm average soil-and-climate boundary from the same time period. Study area denoted in grey.

Fig. 2: North American soil moisture simulations of the 120-year record for the pedocal-pedalfer boundary of: (a) the driest extent (maximum drought; red), driest decile (driest 10\%; orange), wettest decile (wettest 10\%; blue), and wettest extent (maximum wet; green), (b) range between the upper and lower quartile where red is the drier $25 \%$ and blue is the wetter $25 \%$, (c) differences in average soil moisture conditions from the first half the studied record (1895-1953; green) and the last half (1954-2013; blue), (d) average conditions during the 1931-1939 drought (orange) and the 1952-1956 drought (red). Study area denoted in grey.

Fig. 3: Climatic, edaphic, and physiographic properties along the long-term averaged pedocal-pedalfer boundary and climate-only isohyet. Latitude is plotted with: (A) the east-west distance between the two boundaries seen in Fig. 1 (negative values indicate the climate-only boundary occurs west of climate-andsoils boundary), (B) differences in current annual precipitation (PRISM Climate Group, 2015), (C) difference in annual water balance averaged for all years (1895-2014), (D) differences in the summer water balance averaged for all years, (E) difference in elevation, and (F) the total plant available water capacity. State abbreviations are presented in 3A (ND, North Dakota; SD, South Dakota; NE, Nebraska; KS, Kansas; OK, Oklahoma; TX, Texas). Statistical relationships are presented in table 2.

Fig. 4: Geographic extent of soil moisture classes from the three most extreme drought years identified by greatest areal extent of pedocal conditions (aridic and ustic).

Fig. 5. Distribution of calcic soil horizons in the central United States from the National Soil Information Database and displayed using national SSURGO base map. Grey area is the Southern High Plains which met the criteria for climo-sequence analysis.

Fig. 6: Relationships between the long-term annual water balances (1895-2014) in the southern Great Plains and $\mathrm{CaCO}_{3}$ concentration of dominant calcic horizon. Calcic horizon data is from component level NASIS database and water balance average is derived from annual Newhall simulation model runs. 


\section{References}

Arkley, R.J., 1963. Calculation of carbonate and water movement in soil from climatic data. Soil Science 96(4), 239-248.

Bailey, R.G., 2004. Identifying ecoregion boundaries. Environmental management 34(Suppl 1), S14-S26.

Biasutti, M., Sobel, A.H., Camargo, S.J., Creyts, T.T., 2012. Projected changes in the physical climate of the Gulf Coast and Caribbean. Climatic Change 112(3-4), 819-845.

Chadwick, O.A., Chorover, J., 2001. The chemistry of pedogenic thresholds. Geoderma 100(3), 321-353.

Costantini, E.A., Castelli, F., Raimondi, S., Lorenzoni, P., 2002. Assessing soil moisture regimes with traditional and new methods. Soil Science Society of America Journal 66(6), 18891896.

Dregne, H.E., 1976. Soils of Arid Regions. Elsevier, Amsterdam.

ESRI, 2014. Release 10.3 Environmental Systems Research Institute. Redlands, CA.

Forbes, T.R., 1986. The Guy Smith interviews: Rationale for concepts in soil taxonomy, 11. Soil Management Support Services Washington, DC.

Forman, S.L., Oglesby, R., Webb, R.S., 2001. Temporal and spatial patterns of Holocene dune activity on the Great Plains of North America: megadroughts and climate links. Global and Planetary Change 29(1), 1-29.

Gile, L.H., Peterson, F.F., Grossman, R.B., 1966. Morphological and genetic sequences of carbonate accumulation in desert soils. Soil Science 101(5), 347-360.

Gimeno, L., Drumond, A., Nieto, R., Trigo, R.M., Stohl, A., 2010. On the origin of continental precipitation. Geophysical Research Letters 37(13).

Hammer, Ø., Harper, D., Ryan, P., 2001. PAST-PAlaeontological STatistics, ver. 1.89. Palaeontologia electronica 4(1), 1-9.

Herrick, J.E., Sala, O.E., Karl, J.W., 2013. Land degradation and climate change: a sin of omission? Frontiers in Ecology and the Environment 11(6), 283-283.

Hoerling, M., Eischeid, J., Kumar, A., Leung, R., Mariotti, A., Mo, K., Schubert, S., Seager, R., 2014. Causes and predictability of the 2012 Great Plains drought. Bulletin of the American Meteorological Society 95(2), 269-282.

IPCC, 2014. Climate change 2014: impacts, adaptation, and vulnerability. Part B: regional aspects. Contribution of Working Group II to the Fifth Assessment Report of the Intergovernmental Panel on Climate Change. Cambridge University Press, Cambridge, United Kingdom and New York, NY, USA.

Jenny, H., 1994. Factors of soil formation: a system of quantitative pedology. McGraw-Hill, New York, New York, USA.

Küchler, A., 1964. Potential Natural Vegetation of the Conterminous United States: Map. American Geographical Society.

Küchler, A., 1970. A Biogeographical Boundary: The Tatschl Line. Transactions of the Kansas Academy of Science (1903-) 73(3), 298-301.

Lal, R., 2015. Sequestering carbon and increasing productivity by conservation agriculture. Journal of Soil and Water Conservation 70(3), 55A-62A.

Lewis, G.M., 1966. William Gilpin and the concept of the Great Plains region. Annals of the Association of American Geographers 56(1), 33-51. 
Libecap, G.D., Hansen, Z.K., 2002. "Rain Follows the Plow" and Dryfarming Doctrine: The Climate Information Problem and Homestead Failure in the Upper Great Plains, 18901925. The Journal of Economic History 62(01), 86-120.

Little, J.B., 2009. Saving the Ogallala Aquifer. Scientific American 19, 32-39.

Machette, M.N., 1985. Calcic soils of the southwestern United States. Geological Society of America Special Papers 203, 1-22.

Marbut, C., 1935. Soils of the United States, Atlas of American Agriculture, Part III. US Department of Agriculture, Washington, DC.

McMahon, G., Gregonis, S.M., Waltman, S.W., Omernik, J.M., Thorson, T.D., Freeouf, J.A., Rorick, A.H., Keys, J.E., 2001. Developing a spatial framework of common ecological regions for the conterminous United States. Environmental Management 28(3), 293-316.

Miller, D.A., White, R.A., 1998. A conterminous United States multilayer soil characteristics dataset for regional climate and hydrology modeling. Earth interactions 2(2), 1-26.

Monger, H., Martinez-Rios, J., 2000. Inorganic carbon sequestration in grazing lands. In: R. Follett, J. Kimble (Eds.), The potential of US grazing lands to sequester carbon and mitigate the greenhouse effect. . Lewis Publishers, CRC Press, Boca Raton, FL, pp. 87118.

Monger, H.C., Rachal, D.M., 2013. Soil and landscape memory of climate change: how sensitive, how connected. Soc Sediment Geol Spec Pub 104, 63-70.

Newhall, F., Berdanier, C.R., 1996. Calculation of soil moisture regimes from the climatic record. National Soil Survey Center, Natural Resources Conservation Service, US Department of Agriculture, Lincoln, NE.

Parton, W.J., Schimel, D.S., Cole, C., Ojima, D., 1987. Analysis of factors controlling soil organic matter levels in Great Plains grasslands. Soil Science Society of America Journal 51(5), 1173-1179.

Perdrial, J., Thompson, A., Chorover, J., 2015. Soil Geochemistry in the Critical Zone: Influence on Atmosphere, Surface-and Groundwater Composition. In: J.R. Giardino, C. Houser (Eds.), Principles and Dynamics of the Critical Zone. Elsevier, pp. 173-201.

Powell, J.W., Gilbert, G.K., Dutton, C.E., Drummond, W., Thompson, A.H., 1879. Report on the Lands of the Arid Region of the United States: With a More Detailed Account of the Lands of Utah. With Maps, 3. 2nd ed. Government Printing Office, Washington, DC, USA.

Retallack, G.J., 2000. Depth to pedogenic carbonate horizon as a paleoprecipitation indicator?: Comment and Reply COMMENT. Geology 28(6), 572-572.

Retallack, G.J., 2005. Pedogenic carbonate proxies for amount and seasonality of precipitation in paleosols. Geology 33(4), 333-336.

Rossum, S., Lavin, S., 2000. Where are the Great Plains? A cartographic analysis. The Professional Geographer 52(3), 543-552.

Ruhe, R.V., 1984. Soil-climate system across the prairies in midwestern USA. Geoderma 34(3), 201-219.

Salley, S.W., Talbot, C.J., Brown, J.R., 2016. The Natural Resources Conservation Service Land Resource Hierarchy and Ecological Sites. Soil Science Society of America Journal 80(1), $1-9$.

Seybold, C., Herrick, J., Brejda, J., 1999. Soil resilience: A fundamental component of soil quality. Soil Science 164(4), 224-234. 
Soil Survey Quality Assurance Staff, 1994. Soil Climate Regimes of the United States. Soil Conservation Service, USDA, Lincoln, NE.

Soil Survey Staff, 2006. U.S. General Soils Map (STATSGO2).

Soil Survey Staff, 2012. jNSM 1.6.0 - Java Newhall Simulation Model [Software]. Available from http://www.nrcs.usda.gov/.

Soil Survey Staff, 2014. Keys to soil taxonomy. 12 ed. USDA-NRCS, Washington DC.

Soil Survey Staff, 2015. Soil Survey Geographic Database (SSURGO). US Department of Agriculture- Natural Resources Conservation Service, Lincoln, NE.

Steward, D.R., Bruss, P.J., Yang, X., Staggenborg, S.A., Welch, S.M., Apley, M.D., 2013. Tapping unsustainable groundwater stores for agricultural production in the High Plains Aquifer of Kansas, projections to 2110. Proceedings of the National Academy of Sciences 110(37), E3477-E3486.

Strickland, T., Scully, B., Hubbard, R., Sullivan, D., Abdo, Z., Savabi, M., Lee, R., Olson, D., Hawkins, G., 2015. Effect of conservation practices on soil carbon and nitrogen accretion and crop yield in a corn production system in the southeastern coastal plain, United States. Journal of Soil and Water Conservation 70(3), 170-181.

USDA-NRCS, 2006. Land Resource Regions and Major Land Resource Areas of the United States, the Caribbean, and the Pacific Basin, USDA Handbook 296. US Government Printing Office, Washington, DC, USA.

Van Wambeke, A., Hastings, P., Tolomeo, M., 1986. Newhall Simulation Model--A BASIC Program for the IBM PC (DOS 2.0 or later), Dept. of Agronomy, Cornell University, Ithaca, NY.

Winzeler, H.E., Owens, P.R., Waltman, S.W., Waltman, W.J., Libohova, Z., Beaudette, D., 2013. A methodology for examining changes in soil climate geography through time: US soil moisture regimes for the period 1971-2000. Soil Science Society of America Journal 77(1), 213-225.

Zobeck, T., Daugherty, L., 1982. Calculating the depths of soil moisture control sections from laboratory data. Soil Science Society of America Journal 46(4), 792-795. 


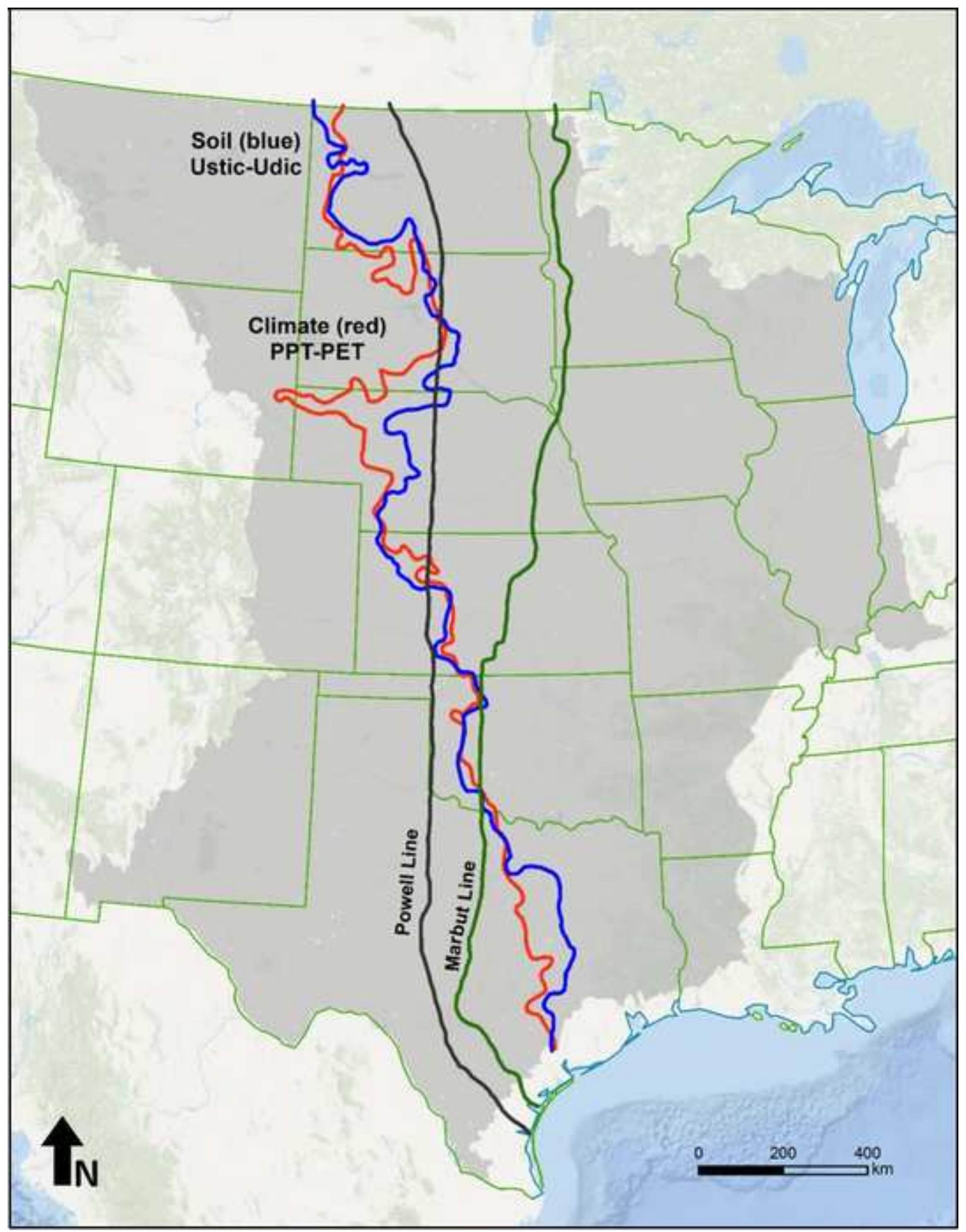




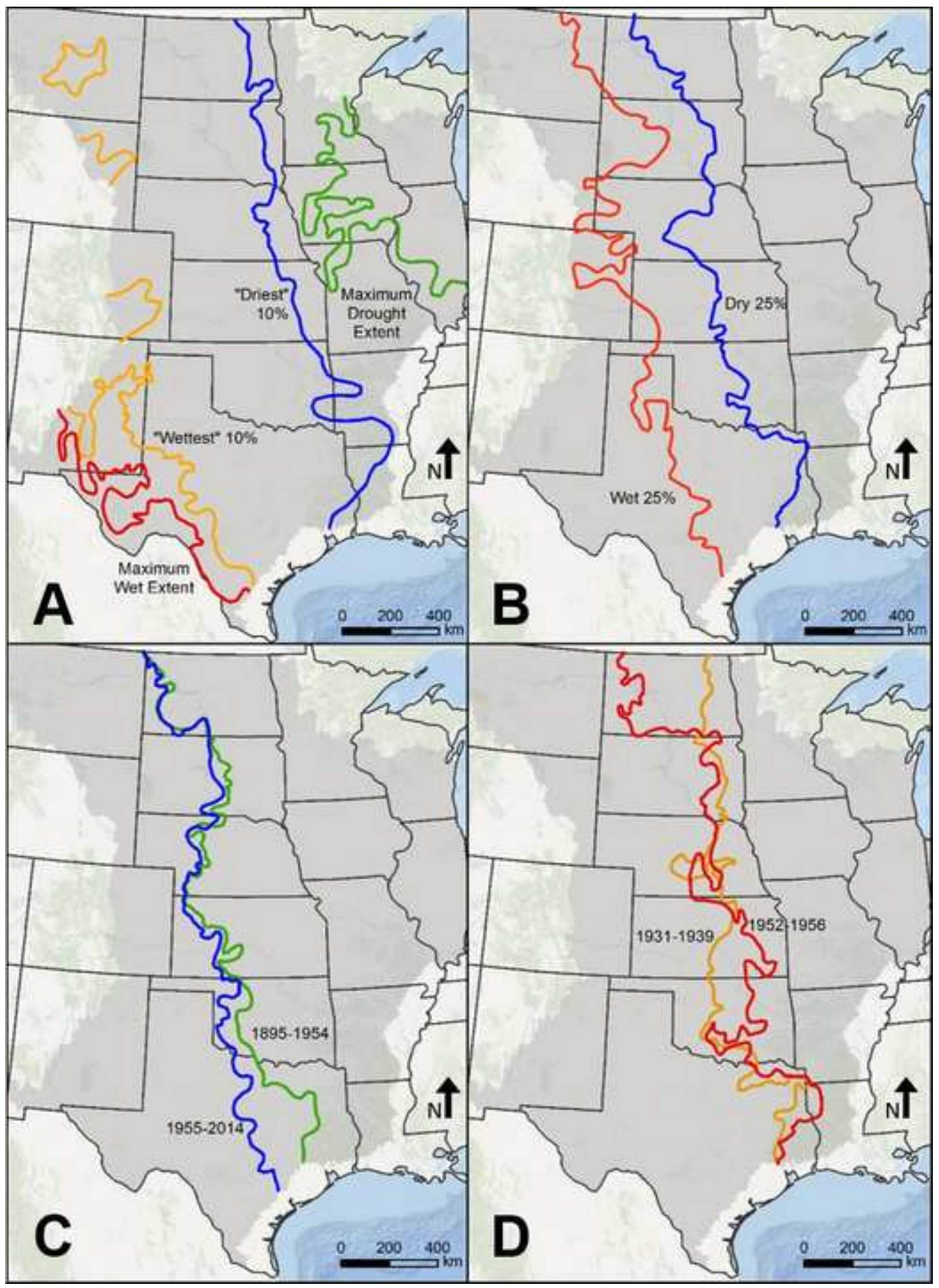




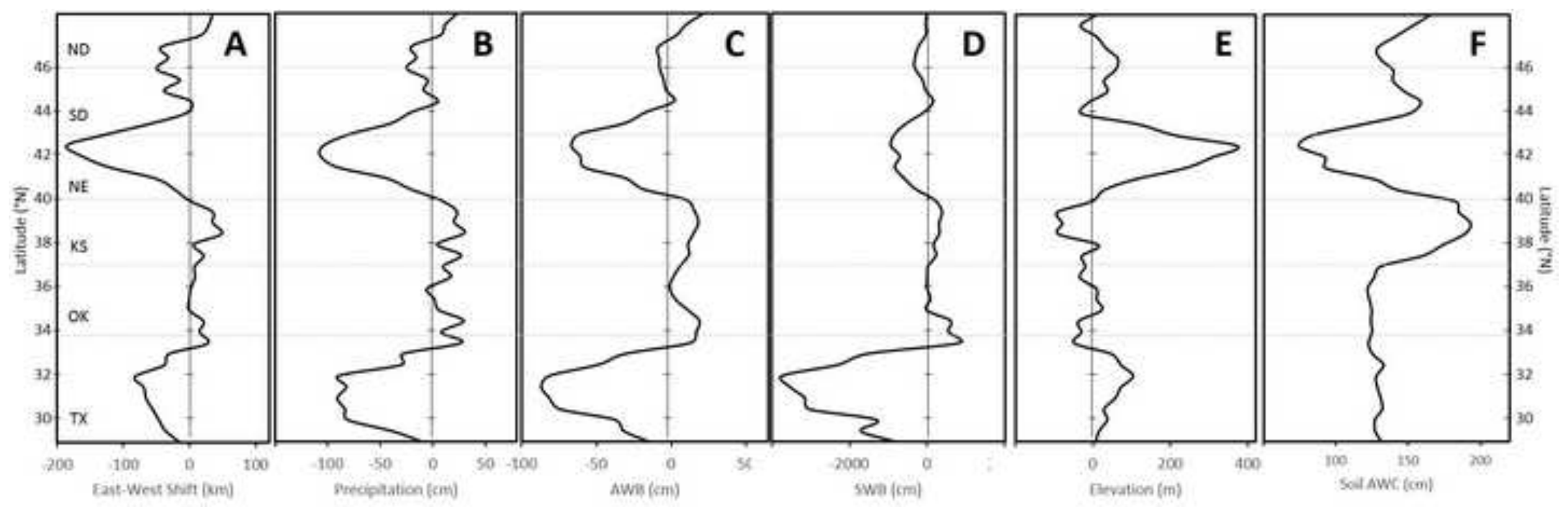




\section{4}

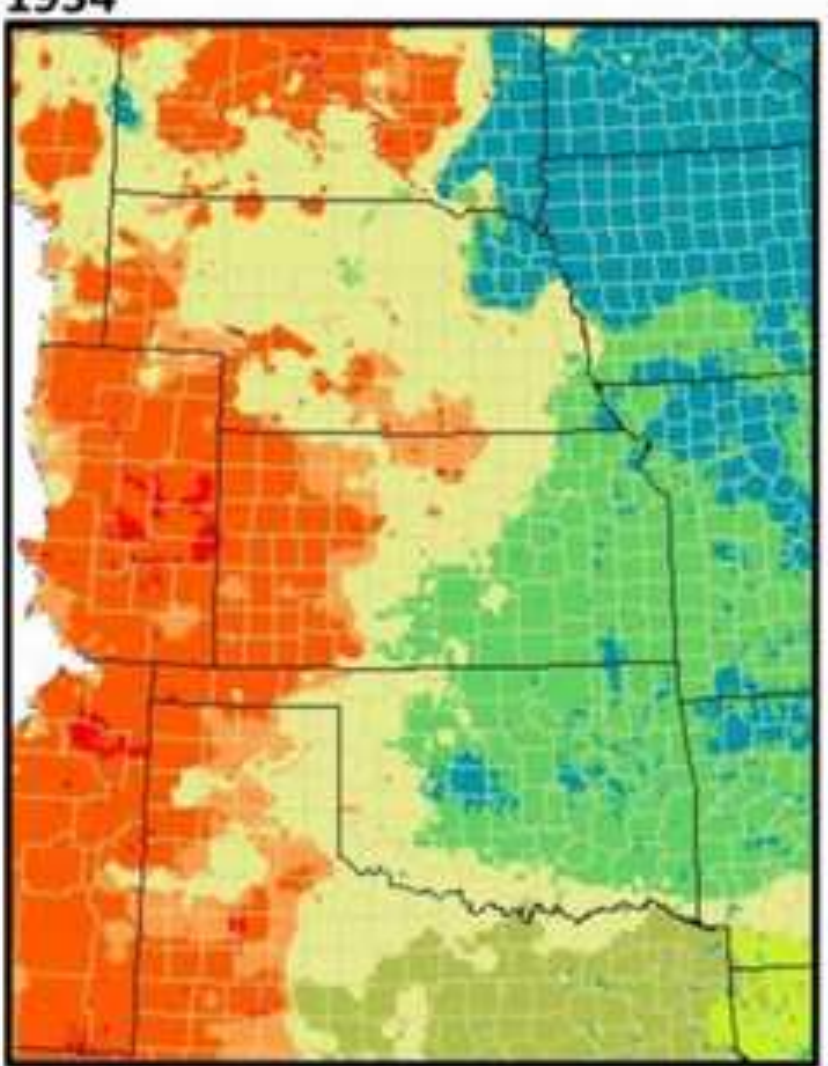

PERUDIC

UDIC - TYPIC

UDIC - DRY

USTIC - WET

USTIC - DRY
1956

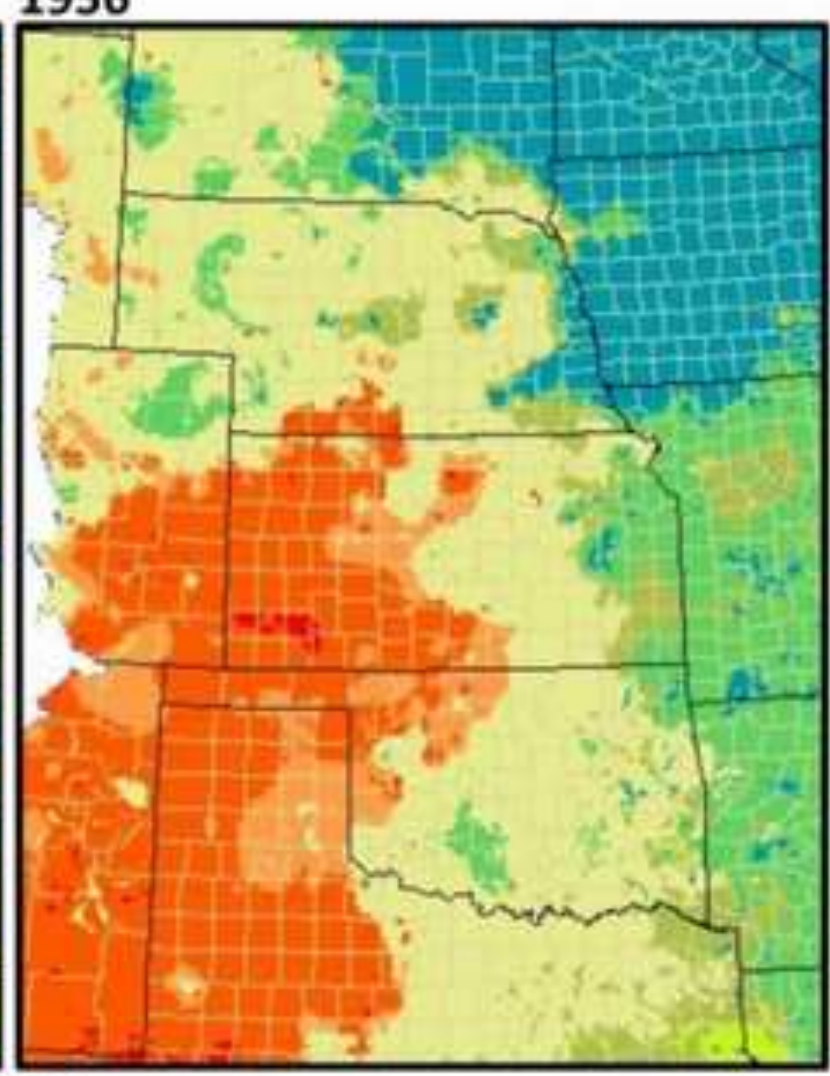

USTIC - TYPIC
ARIDIC - WEAK

ARIOIC - TYPIC

ARIDIC-EXTREME
2012

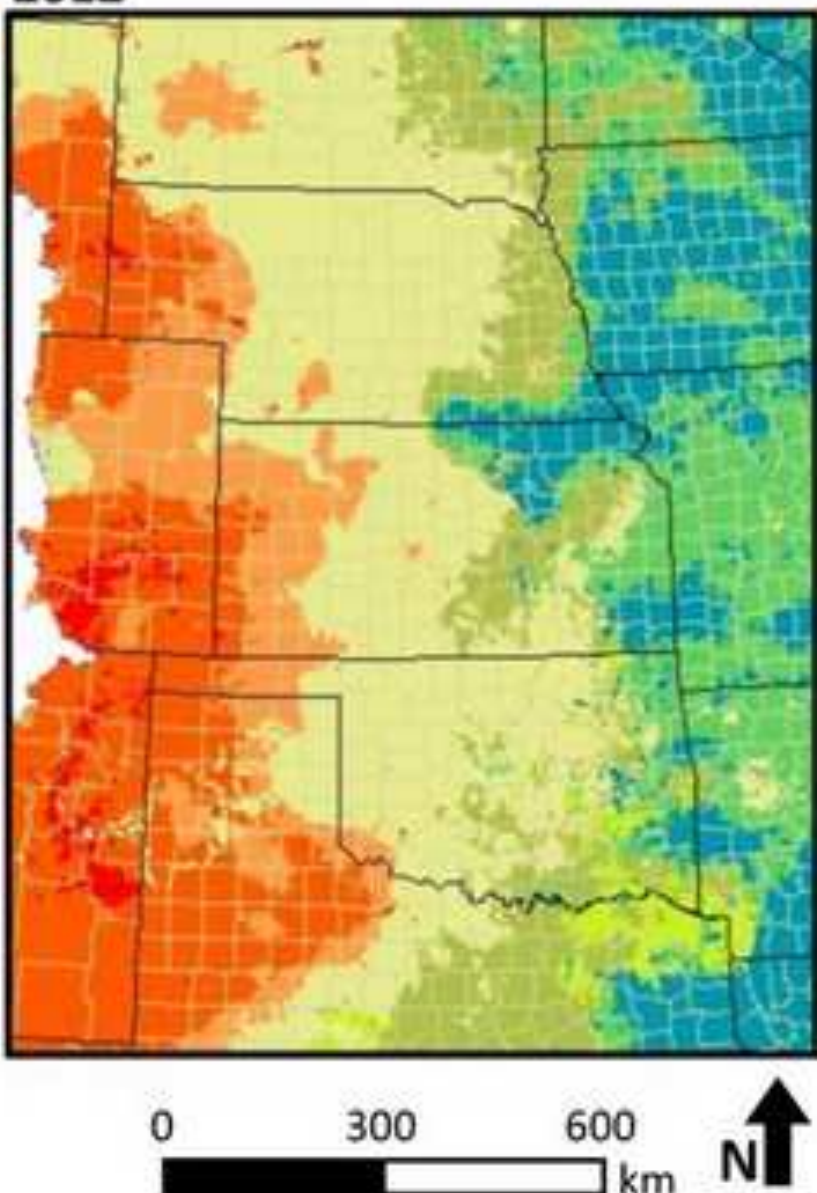


Figure 5

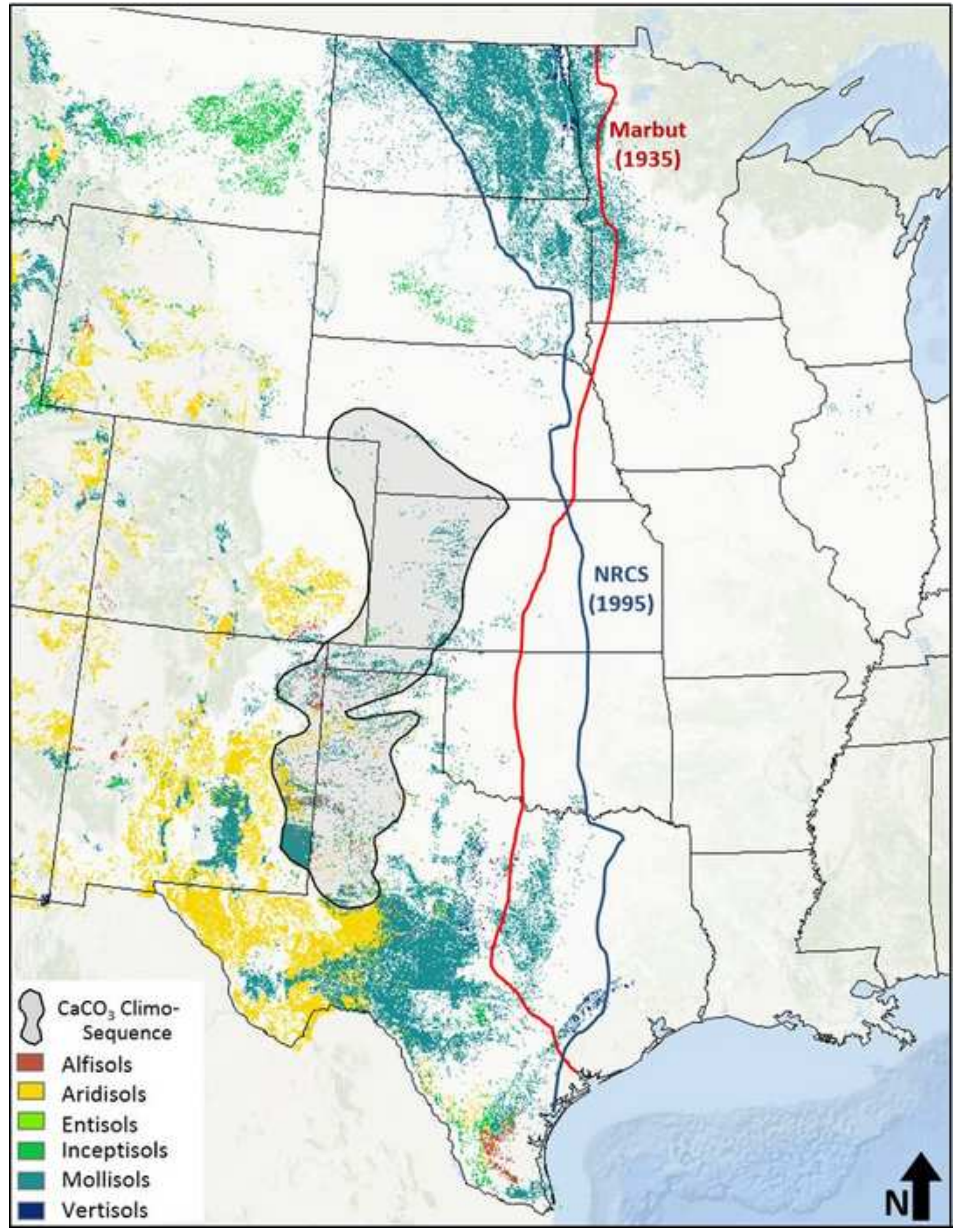




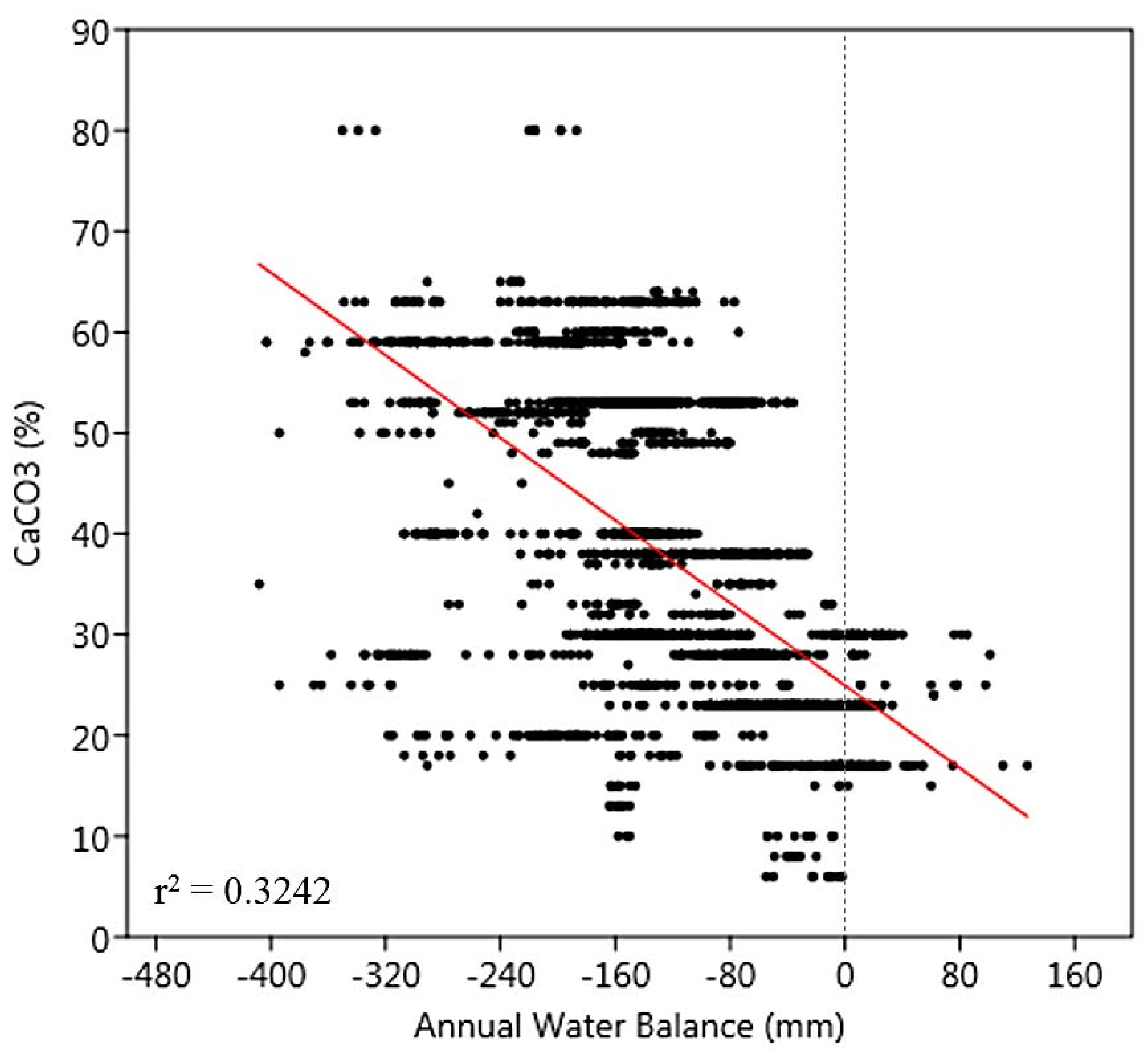

